DID UNILATERAL DIVORCE RAISE DIVORCE RATES? EVIDENCE FROM PANEL DATA

Leora Friedberg

Working Paper 6398 
NBER WORKING PAPER SERIES

\title{
DID UNILATERAL DIVORCE RAISE \\ DIVORCE RATES? EVIDENCE FROM PANEL DATA
}

\author{
Leora Friedberg
}

Working Paper 6398

http://www.nber.org/papers/w6398

\section{NATIONAL BUREAU OF ECONOMIC RESEARCH \\ 1050 Massachusetts Avenue \\ Cambridge, MA 02138 \\ February 1998}

I wish to thank Jon Gruber, Shoshana Grossbard-Shectman, Jerry Hausman, Jim Poterba, and especially Aaron Yelowitz for many useful discussions, the editor and anonymous referees for their comments, and Margaret Brinig for sharing her data on state divorce laws. Any opinions expressed are those of the author and not those of the National Bureau of Economic Research.

(C) 1998 by Leora Friedberg. All rights reserved. Short sections of text, not to exceed two paragraphs, may be quoted without explicit permission provided that full credit, including $\odot$ notice, is given to the source. 
Did Unilateral Divorce Raise Divorce Rates?

Evidence from Panel Data

Leora Friedberg

NBER Working Paper No. 6398

February 1998

JEL Nos. J12, K39

\section{ABSTRACT}

This paper revisits the evidence on the impact of unilateral divorce laws on divorce rates in the United States. Most states switched from requiring mutual consent to allowing unilateral or nofault divorce between 1970 and 1985, while the national divorce rate more than doubled after 1965 . According to the Coase theorem, however, the legal shift should have had no effect on divorce rates. Recent papers using cross-sectional micro data have disputed the empirical importance of unilateral divorce, disagreeing in particular about controls for state-level heterogeneity in divorce propensities. This paper uses a panel of state-level divorce rates which includes virtually every divorce in the U.S. over the entire period of the law changes. Adding comprehensive controls - year and state fixed effects and state fixed trends - for changing unobservable divorce propensities reveals that the divorce rate would have been about $6 \%$ lower if states had not switched to unilateral divorce, accounting for $17 \%$ of the increase in the divorce rate between 1968 and 1988 . Additional results in this paper demonstrate that the type of unilateral divorce law that states adopted matters. Weaker versions of unilateral divorce, which retain elements of mutual divorce, raised the divorce rate significantly, but by less than the strongest versions of unilateral divorce did.

\section{Leora Friedberg}

Department of Economics, 0508

University of California, San Diego

9500 Gilman Drive

La Jolla, CA 92093-0508

and NBER

lfriedber@weber.ucsd.edu 
Since early 1996, at least eight states have begun to consider rolling back unilateral and no-fault divorce - a major reversal of the liberalizing trend in divorce laws which began around 1970. ${ }^{1}$ The proponents of tightening the divorce regime often argue that making divorce more difficult will strengthen families. However, both theoretical and empirical evidence is decidedly mixed over whether the "no-fault revolution" actually contributed to the sharp increase in divorce rates in the U.S. observed over the last thirty years.

Thorough empirical work on the subject by Peters (1986) was followed by a comment by Allen (1992) and a reply by Peters (1992). Using the same cross-section of women observed in 1979 , Peters found no role for the switch to unilateral divorce in explaining rising divorce rates, while Allen found a significant impact. The differences in their results centered on controls for geographical heterogeneity in divorce propensities. In this paper I address the dispute by using a panel of state-level divorce rates. The sample includes virtually every divorce in the U.S. over the entire duration of the law changes and allows thorough controls for heterogeneity in divorce propensities across states and over time - which turn out to be crucial to the results. Including state-specific trends allows unobserved state divorce propensities to trend linearly and even quadratically over time and reveals that unilateral divorce raised divorce rates significantly and strongly.

An additional difficulty in this literature arises in defining precisely what is unilateral divorce. Peters and Allen disagreed whether separation requirements qualify as unilateral divorce. Brinig and Buckley (1996) questioned whether divorce in states that retain fault grounds for property settlement can be considered unilateral. The empirical analysis in each of those papers retained a binary classification of divorce laws, yet the impact of different types of unilateral divorce can be tested. I find here that the type of unilateral divorce matters. States that adopted divorce laws which were more strongly unilateral had greater increases in the divorce rate. Nevertheless, the evidence shows that adopting any type of unilateral divorce raised the divorce rate.

I combine both sets of results to arrive at final estimates of the impact of unilateral divorce. The final estimates suggest that the divorce rate would have been about $6 \%$ lower in

\footnotetext{
1 See for example Leland (1996) in Newsweek.
} 
1988 if no type of unilateral divorce had been adopted in those states that switched to unilateral divorce after 1968. The move towards unilateral divorce accounted for $17 \%$ of the increase in divorce rates between 1968 and 1988. I also demonstrate that the law changes do not appear to be endogenous, and that the effect of unilateral divorce on divorce behavior was permanent, not temporary.

\section{MEASURING THE IMPACT OF UNILATERAL DIVORCE}

The divorce rate in the United States soared in the 1960s and 1970s, rising from 2.2 per thousand people in 1960 to 5.0 in 1985, as demonstrated in Figure 1 by the upper line. ${ }^{2}$ During that time, states substantially liberalized and simplified their divorce laws. For example, in the absence of fault most states once required mutual divorce, to which both spouses had to consent. Many states abandoned mutual divorce requirements in favor of unilateral divorce, which required the willingness of only one spouse to divorce. Most states also adopted some form of no-fault divorce, eliminating the need for one spouse to prove a transgression by the other. The lower line in Figure 1 shows the rise in the populationweighted percentage of states with unilateral no-fault divorce starting in $1968 .{ }^{3}$ Casual observation suggests attributing at least some of the increasing prevalence of divorce to the widespread shift to unilateral and no-fault divorce, which appears to make divorce simpler. On the other hand, lawmakers and legal experts at the time argued that the motivation for changing the laws was to bring law books into alignment with actual practice and to eliminate the need to assign blame during a divorce, but not to make divorce easier. ${ }^{4}$

\footnotetext{
2 Cherlin (1992) documented that the divorce rate rose steadily in the late nineteenth and early twentieth centuries. After a sharp peak during World War II, it dropped below trend in the 1950s. The rise in the 1960 s and 1970 s looks especially stark compared to the low level in the 1950s, but it also was steeper than the century-long trend.
}

3 Figure 1 shows the percentage of states with any type of unilateral divorce broadly or narrowly defined. Section II discusses the classification of unilateral divorce laws.

4 This intention is stated in the letter of the law in several states, such as Wisconsin. With respect to actual practice at the time, studies showed that many divorces did not involve real transgressions, regardless of legal requirements (Freed and Foster [1979]). As an example, news stories several years ago reported that, while the ex- 
A theoretical model of divorce laid out by Peters (1986) and Becker (1981) showed that, under perfect information and costless bargaining, a marriage will be dissolved when it is efficient to do so: "when the joint value of the marriage is less than the sum of the values of opportunities that face each spouse at divorce" (Peters, p.438). Barring asymmetric information and transactions costs, a change in the law from mutual to unilateral divorce would not make divorce more likely. By the Coase theorem, it would simply redistribute property rights from the spouse who wished to remain in the marriage to the spouse who wished to leave. Thus, under mutual divorce the spouse who wished to leave the marriage had to compensate the spouse who wished to stay in order to obtain the efficient outcome of divorce, while under unilateral divorce the spouse who wishes to stay in the marriage must compensate the one who wishes to leave. The law change would alter the property rights and resulting compensation scheme between the spouses without making them more likely to divorce.

\section{Estimation Approach}

The typical test of whether the Coase theorem applies, and hence the type of divorce law does not matter, asks whether people living under unilateral divorce laws are no more likely to divorce than people living under mutual divorce laws. Peters (1986) and Allen (1992) took this approach, using the same cross-sectional data but arriving at different conclusions. Both used a supplement from the 1979 Current Population Survey of individuals' marital histories. They estimated a logit on a sample of those women who reported being married in 1975, where the left-hand side variable was one if a woman was divorced in 1978 and zero if she stayed married. Controlling for demographic variables believed to affect the likelihood of divorce, they used the variation of divorce regimes across states in 1978 to identify whether unilateral divorce raised divorce rates.

wife of former Governor Doug Wilder of Virginia had divorced him on the grounds of cruelty, they had fabricated the grounds in order to obtain a divorce which they both wanted. Similar anecdotes suggested to the legal and legislative community that blame was not necessary to determine whether a couple should divorce. 
Peters and Allen disagreed about including controls for geographic differences in divorce propensities. Peters estimated a coefficient on unilateral divorce of virtually zero. Allen demonstrated that, when region dummies and a state's 1970 divorce rate were excluded from the regression, the coefficient on the law became significant and of an important magnitude, implying that unilateral divorce raises the probability of divorce by $1.4 \%$. $\mathrm{He}$ suggested that the region dummies did not serve a purpose in explaining divorce independently but simply absorbed much of the variation in divorce laws. ${ }^{5}$

With panel data, the role of cross-state heterogeneity in divorce behavior can be explored in more detail, without having to be specific about the sources of heterogeneity. State fixed effects control for unobserved influences on divorce that vary across states, so that the effect of the divorce law is identified from its variation within a state over time. For this purpose, I assembled a panel of state-level divorce rates over a twenty year period. This data records virtually every divorce in the United States. ${ }^{6}$

The relationship which Peters estimated can be easily adapted for a panel of state divorce rates. Her regression took the following form:

$$
\text { divorce }_{i s}=a_{0}+a_{1} * \text { unilateral }_{s}+a_{2}{ }^{\prime} * Z_{i s}+e_{i s} \text {, }
$$

which describes a population of women who are initially married. Each observation is subscripted for the individual $i$ and the state $s$ in which she lives. The variable divorce is one if the woman is divorced when observed and zero if she is not. Of interest is the variable unilateral, which is one if the woman's state has a unilateral divorce law and zero if it has a mutual divorce law. Demographic characteristics which may affect the propensity to divorce, such as education, number of children, and age, are included in $Z .^{7}$

\footnotetext{
5 Allen also disagreed that the Coase theorem could apply to this situation, arguing that marriage is not a state with perfectly defined property rights and that divorce involves transaction costs. This disagreement does not interfere with the empirical approach of measuring the impact of unilateral divorce laws on divorce propensities.

6 Using a longitudinal survey like the Panel Study of Income Dynamics might be preferable, since it has more individual level information on the correlates of divorce. However, it has the disadvantages of a very small sample size and potential bias due to sample attrition being correlated with divorce.
}

7 Peters estimated a logit, not a linear probability model as expressed in (1). She used age, education, race, 
To estimate the relationship with state-level time-series data, add up equation (1) over observations within a state and divide by population to obtain the following:

$$
\text { divrate }_{s t}=b_{0}+b_{I} * \text { unilateral }_{s t}+b_{2 s} * \text { state }_{s}+b_{3 t} * \text { year } t+u_{s t}
$$

Now, the dependent variable divrate is the state level divorce rate, which is the number of divorces that occur within a state each year divided by the state population in thousands. ${ }^{8}$ The disturbance $u$ is equal to $\left(\Sigma_{i \in s} e_{i s}\right) / p o p_{s t}$, the sum of all individual disturbances within a state each year divided by the population. This makes $u$ heteroscedastic, so population is used to perform weighted least squares. ${ }^{9}$ Using a panel allows the inclusion of year, which are year effects that control for evolving unobserved national attributes that affect the likelihood of divorce.

The demographic characteristics $Z$ from (1) might become, for example, the number of urban residents or the number of children in the state. Equation (2) assumes that the demographic characteristics are unchanging within a state over time. The coefficients cannot be separately identified, so the state characteristics are subsumed in the fixed effect state. The use of state effects, which is only possible with a panel, is advantageous because it explains divorce patterns flexibly, rather than having to include all relevant divorce covariates explicitly. However, the factors which influence divorce may vary within a state over time, confounding the estimates of the state effects. That will also bias the estimate of the coefficient on unilateral if the changing factors are correlated with the law changes across

number of kids under 18 added linearly and squared, an SMSA dummy, and a dummy for being in the labor force as right hand side variables.

8 To be precise, divrate should measure the number of divorces per thousand married women, but that information is not readily available. To get at the true divorce rate, I used the sampling weights to aggregate data from the Current Population Survey and obtain estimates of the stock of married women by state and year, in order to renormalize the measured divorce rate. This had the effect of strengthening the estimated impact of unilateral on divorce rates, but not significantly. In the rest of the paper I use the available measure of the divorce rate, principally because the Current Population Survey did not report exact state identifiers for numerous states before 1978 .

9 The intuition behind weighted least squares is that a positive effect of unilateral in, say, California will carry more weight than a positive effect in New Hampshire. 
states, and if such factors do not change at a national level uniformly and get picked up by the year effects. The specification in (2) can be relaxed further to allow for such changing influences within a state over time, as follows:

$$
\begin{aligned}
\text { divrate }_{s t}= & c_{0}+c_{l} * \text { unilateral }_{s t}+c_{2 s} * \text { state }_{s}+c_{3 t} * \text { year }_{t}+c_{4 s} * \text { state }_{s} * \text { time }_{t} \\
& +c_{5 s} * \text { state }_{s} * \text { time }_{t}{ }^{2}+u_{s t} .
\end{aligned}
$$

time is a time trend, so the interaction terms state $*$ time and state $*$ time $e^{2}$ are linear and quadratic trends for each state. They capture quadratic trends in state-level characteristics that influence divorce, with the slopes of the trends allowed to vary across states. ${ }^{10}$ Thus, (3) represents an extremely flexible way to control for heterogeneous divorce behavior, identifying the impact of unilateral from a jump in the pattern of divorce which is distinguishable from a smooth quadratic. While it remains possible that this specification still does not capture all of the factors explaining divrate, additional evidence against the endogeneity of unilateral will be discussed later.

\section{Data}

The longitudinal data on state divorce rates cover all fifty states and the District of Columbia from 1968 to 1988 . The "no-fault revolution" began in 1970 when California replaced all fault grounds for divorce - such as adultery and cruelty - with the sole ground of irretrievable breakdown of the marriage. Over the following decade and a half, every state legalized no-fault grounds for divorce. As reported in Table 1, most states adopted unilateral divorce as well, under which the no-fault grounds do not require the agreement of both spouses. ${ }^{11}$ Table 1 also distinguishes among alternative categorizations of divorce laws. For comparability, the results in this section use Peters' classification of unilateral divorce, which

10 The use of state-specific linear trends follows Jacobson, LaLonde and Sullivan (1993).

11 The information in Table 1 is derived from Freed and Foster (1977, 1979, 1981), Freed and Walker (1990), Sepler (1981), and Brinig and Buckley (1996). 
excludes those states where the only unilateral ground is living separate for a length of time. Later I relax the restriction that separation requirements have no effect on divorce rates.

Divorce rates by state, reported in Vital Statistics of the United States, are shown in Table 2. The sample covers virtually every divorce in the country for twenty years. It is not complete because, in certain states in certain years, Vital Statistics reports that the data was collected in an irregular or incomplete fashion. A set of dummies, listed in the Appendix, control for those instances. A few missing values are also listed in the footnotes to Table 2 .

\section{Results with State and Year Effects}

The coefficient on unilateral turns out to be quite sensitive to the nature of state and time controls used, as Allen demonstrated. The results of estimating the basic regression and then adding state and year effects, as in equation (2), are shown in Table 3. Regression 3.1 has no state or year effects. The estimated coefficient on unilateral is statistically significant and very large, at $1.802(0.087)$, with an adjusted $R^{2}$ of 0.314 . Similar results are obtained with year effects in regression 3.2. Regression 3.3 adds state fixed effects, which are meant to absorb everything affecting divorce behavior at the state level that is constant over time. Adding state effects drives down the coefficient on unilateral to $0.004(0.056)$, while raising the explanatory power of the regression to 0.946 . The state effects appear to explain most of the pattern of divorce, which had previously been picked up by the divorce law.

\section{Adding State-Specific Trends}

The results above make it clear that unobserved covariates and unobservable divorce propensities - which may include, for instance, social attitudes, religious beliefs and family size - are the main determinants of divorce. However, assuming that they are constant within a state over twenty years or changing over time but uniform across the nation is restrictive. State-year interactions are completely unrestrictive but not feasible. State-specific trends, though, are a feasible alternative that allow the unobserved state factors influencing divorce to have a linear trend, with the trend allowed to vary across states. The estimated coefficient on 
unilateral retains the same interpretation as before: a positive coefficient measures by how much a unilateral divorce law raises a state's divorce rate, which now might also have a positive or negative trend.

Regression 3.4 includes the state-specific trends. The state trends are jointly significant and raise the adjusted $\mathrm{R}^{2}$ to 0.976 . More importantly, the coefficient on unilateral is much larger and has a smaller standard error. The estimate of $0.447(0.050)$ means that unilateral divorce raised the divorce rate by more than 0.4 divorces per thousand people, a substantial impact relative to the average divorce rate over the period of 4.6.

\section{Why State-Specific Trends Matter}

Why the big change in the estimate of unilateral's coefficient when state trends are added? It is because imposing a flat state divorce propensity misspecifies the underlying divorce behavior and in turn camouflages the variation induced by the law change. Naturally, imposing constant state divorce propensities when they are really trending will bias the estimates of the constants - the estimated intercepts will reflect the average of the trend instead of the true intercept, which is the state's initial divorce propensity only. If, further, the omitted slopes are correlated with the law changes, the result is omitted variable bias. The resulting bias can be depicted visually, as in Figure 2-A. The upper line in Figure 2-A is California's actual divorce rate, with the box signaling the year of the law change. The lines near the bottom show what remain of the divorce rate to be explained by the law change in each regression. The dashed line removes the constant and the state and year effects from regression 3.3, and the solid line removes the (negative) state trend as well from regression 3.4. Both lines jump in the year of the law change, but the dashed line from regression 3.3 ultimately confounds the influence of unilateral with the omitted downward trend in California's divorce propensity, biasing downward the estimated effect of unilateral. The solid line, on the other hand, demonstrates that, controlling for all other influences, the law change raised the divorce rate permanently. Figure 2-B illustrates the same point for 
Michigan. While the dashed line obscures the effect of unilateral, the solid line shows that the law change raised the divorce rate.

The possibility remains that the unobservables exhibit more complex dynamic behavior than can be captured by the linear trend. Therefore, regression 3.5 adds a quadratic in the time trend for each state, which places stronger restrictions on the kind of variation in the divorce rate that can be attributed to the law change. Now, the effect of unilateral is identified from a break in the pattern of divorce that is distinguishable from a smooth quadratic. The state quadratic terms in regression 3.5 are jointly significant, raising the adjusted $\mathrm{R}^{2}$ once more. Meanwhile, the estimated coefficient on unilateral is virtually unchanged 0.441 (0.055), compared to $0.447(0.050)$ without the quadratics. The estimate of unilateral's impact is robust even when the underlying divorce behavior is parameterized very flexibly.

The strongly significant coefficient on unilateral when state trends are included indicates that both Peters' and Allen's regressions were misspecified. Unless the individuallevel demographic controls he used fully explain the divorce rate, Allen - by omitting any controls for state divorce propensities - was naturally more likely to find an impact of the law change, as regression 3.1 demonstrated. Yet, Peters' approach of including the state's 1970 divorce rate was similar to including only the state fixed effect as in regression 3.3 , obscuring the impact of unilateral.

\section{WHAT IS UNILATERAL DIVORCE? \\ Classification of State Divorce Laws}

The theory regarding unilateral divorce is concerned simply with whether one partner can end the marriage without the consent of the other, but what constitutes unilateral divorce in practice is not so clear-cut. One reason it requires some care is that most of the legal scholarship has focused on whether divorce grounds are fault or no-fault, rather than mutual or unilateral. However, no-fault divorce is not synonymous with unilateral divorce, which is the subject of the Coase theorem. A few states (such as Delaware and Arkansas) allow no-fault grounds but require mutual agreement on them and are classified as having mutual divorce. 
Two further issues arise in the classification of state laws, both of which I will test for. Some states allow unilateral divorce only if the couple has lived separately for a length of time. Peters classified those states as having mutual divorce. She argued that separation requirements impose a large cost to divorce unilaterally, so that it would continue to be in the interest of the spouse who wishes to leave the marriage to compensate the spouse who wishes to remain in the marriage in order to divorce promptly. Allen reclassified separation states as having unilateral divorce but found little change in the estimated effect of unilateral. This issue is addressed here more thoroughly by allowing for the two types of unilateral divorce to have different effects on the divorce rate. According to Peters' hypothesis, separation requirements will have an insignificant effect on the divorce rate, compared to other no-fault grounds. The strategy employed here allows separation requirements to have a smaller but still significant effect on divorce.

A final issue raised by Brinig and Buckley (1996) concerns the grounds for property settlement and alimony. Some states grant no-fault divorces but still allow fault to be considered in the division of property and determination of alimony. Brinig and Buckley argue that fault considerations in property division raise the cost of divorce for the spouse who wishes to leave, in effect keeping the property rights with the spouse who wishes to stay in the marriage. Brinig and Buckley classify states as no-fault only if they have no-fault property division as well. ${ }^{12}$ Again, I test their hypothesis explicitly by allowing separate effects on divorce for states that have unilateral divorce with no-fault property division or with fault property division.

\section{Estimating the Impact of Different Unilateral Divorce Laws}

In Table 4, I report the results of including separate variables for the different types of unilateral divorce. Regressions 4.1 and 4.2 explore the impact of unilateral divorce with separation requirements. If separation requirements raise the cost of divorce, in effect keeping

\footnotetext{
12 Another condition for no-fault divorce in Brinig and Buckley's classification is that a state not retain any fault grounds for divorce. This does not seem to be relevant to the definition of unilateral divorce, however.
} 
some of the property rights with the spouse wishing to stay in the marriage, it would be reflected in a smaller or insignificant coefficient. In regression 4.1, the impact of both types of unilateral divorce is statistically significant. The coefficient on unilateral divorce with separation requirements of $0.167(0.059)$ is statistically different from the coefficient of 0.450 $(0.050)$ on strict unilateral divorce, as indicated by the reported $\mathrm{p}$-value of the F-test. Therefore, the effect of unilateral divorce with separation requirements is substantially smaller but still positive. $^{13}$

Regressions 4.3 and 4.4 allow a distinct effect of unilateral divorce depending on whether grounds for property division are no-fault or fault. Even if divorce grounds are nofault, fault considerations in property settlement and alimony may strengthen the position of the spouse who wishes to stay in the marriage. In 4.3 the coefficient on unilateral divorce with fault property division falls to $0.392(0.056)$, significantly different from the coefficient on strict unilateral divorce at a $96.7 \%$ confidence level. The coefficient on strict unilateral divorce, with no-fault grounds for property division, is $0.545(0.068)$, somewhat larger than the coefficient of $0.447(0.050)$ when grounds for property division are ignored.

Regression 4.4 combines the approaches taken in 4.1 and 4.3 by allowing for a multiple classification of unilateral divorce. In 4.4 the coefficient on very strict unilateral divorce unilateral divorce without separation requirements and without fault grounds for property division - is reported in the first row and rises to 0.549 (0.067). It implies a powerful effect on divorce rates, while the other three types of unilateral divorce have smaller effects. The next largest coefficient is $0.396(0.056)$ for unilateral divorce without separation requirements but with fault property division. Unilateral divorce with separation requirements has a smaller impact on divorce, with respective coefficients of $0.133(0.091)$ and $0.192(0.078)$ without fault

13 Regression 4.2 allows distinct effects of different required lengths of separation. With much less variation among states in the lengths required, these results are less informative. The coefficient on a twelve month separation requirement is statistically significant and is similar to the coefficient on strict unilateral divorce. The coefficients on the other lengths of separation are far from being significant. The results indicate that twelve months is not too long to wait for the spouse who wishes to leave the marriage, when the alternative is mutual divorce, but that waiting longer might impose an excessive cost. 
grounds and with fault grounds for property settlement. Though not significantly different, the two coefficients are in reverse order from what would be expected.

To sum up, this section finds that the type of unilateral divorce a state adopted mattered. The strictest unilateral divorce, without separation requirements or fault considerations in property division, raised the divorce rate by 0.549 per thousand people $-11.9 \%$ of the average of 4.6 during the sample period. As Peters and Brinig and Buckley hypothesized, but did not test, weaker versions of unilateral divorce did have smaller effects on the divorce rate - but their effects were still positive. Fault-based property division proved less of a constraint on divorce behavior than separation requirements, according to the evidence. Overall, the results strengthen conclusions about the impact of switching to any type of unilateral regime. The estimates from regression 4.4 show that the divorce rate would have been $6.4 \%$ lower in 1988 if no type of unilateral divorce had been adopted in those states that switched. ${ }^{14}$ The move towards unilateral divorce after 1968 accounted for $17.1 \%$ of the increase in divorce rates between 1968 and 1988 .

\section{ADDITIONAL RESULTS}

\section{Endogenous Legislation}

Any analysis of how legal changes affect behavior raises the question of endogeneity. In the case of divorce, it might be that rising divorce rates caused the law to be changed or that increasing permissiveness towards divorce, which in turn raised divorce rates, did - not that the law changes caused divorce rates to rise. Several authors argue against this. ${ }^{15}$ Also, Peters asserted that interest groups of divorcing individuals were not part of the debate over no-fault divorce laws and that proponents of the change were primarily legal scholars. Unfortunately, it is difficult to come by instruments in order to test properly for endogeneity. ${ }^{16}$

\footnotetext{
14 Estimating the relationship with the log of the divorce rate on the left hand side yields very similar conclusions.

15 For example, legal scholars Freed and Foster (1979) and Sepler (1981).

16 An instrument must be correlated with the law changes but not with the divorce rate independently and must also, for purposes here, vary across state and time. In a time series study, Sepler used as a control the number of articles about no-fault divorce in legal journals, which does not vary across states. Other potential instruments relate
} 
An indication of whether legislation might be endogenous can be found in the correlation across states between initial divorce rates and the likelihood and chronology of the law changes. It does turn out that a state's 1968 divorce rate is a reasonable predictor of whether a state adopted strict unilateral divorce - with a correlation coefficient as high as 0.31 (0.03), depending on the type of unilateral divorce considered. ${ }^{17}$ This result is consistent with similar findings reported in Peters (1992). However, the initial divorce rate is not correlated with when a state adopted unilateral divorce. ${ }^{18}$

A similar conclusion results from a strategy employed by Gruber and Hanratty (1995). In their regression they added a lead dummy variable for whether a law change would occur in the subsequent year. Under the null hypothesis in which causality goes from the law change to the left-hand side variable, the lead dummy should have a coefficient of zero. Otherwise, if there is reverse causality or some other type of endogeneity, then the coefficient will be different from zero. Regression 5.1 in Table 5 shows that the coefficient on the lead dummy of $0.004(0.067)$ is extremely small and statistically indistinguishable from zero.

Therefore, although state divorce propensities do appear to be related to whether a state adopted unilateral divorce (and what type it adopted), the evidence bolsters the identifying assumption that prevailing state characteristics did not influence the timing of the legal change. These results support the use of panel data to identify the impact of unilateral divorce from variation in divorce laws within states over time, instead of across states at a point in time.

to the composition of the legislature (number of women, number of divorced people, etc.) but are difficult to obtain.

17 All but five states had some type of unilateral divorce by the end of the time period, which does not yield a very informative correlation coefficient (only $0.09(0.56)$ ) with the divorce rate in 1968. The correlation coefficient rises when stricter versions of unilateral divorce are considered. It is $0.27(0.06)$ when unilateral divorce excludes separation requirements and $0.31(0.03)$ when unilateral divorce excludes fault grounds for property settlement. The magnitudes are almost the same when omitting states already with unilateral divorce in 1968, thus focusing on whether states without unilateral divorce adopted it.

18 The correlation coefficient between the 1968 divorce rate and the subsequent year in which a state adopted unilateral divorce is $-0.10(0.56)$ when any type of unilateral divorce is considered and is of a similar magnitude and lack of significance when stricter types of unilateral divorce are considered. 


\section{Timing}

Given the emphasis on the dynamics of the unobserved factors affecting divorce, it is instructive to explore whether the estimation properly captures the dynamics of how adopting a unilateral divorce law affected divorce. Two particular issues arise in this regard. One issue is whether the response to the law change was permanent, as modeled, or in fact transitory. Another is whether the length of the panel is appropriate.

First, the response to the legal change might have been a temporary acceleration of divorce - perhaps from a "backlog" of bad marriages breaking up earlier than otherwise rather than a permanent change in divorce propensities. Adding dummies for the years of and immediately following the law change indicate the duration of unilateral's impact. If the law change has only a temporary effect, we would expect a positive coefficient on the lag dummies and an insignificant coefficient on unilateral. The results are shown in regressions 5.2-5.4 of Table 5, of which the most illustrative is 5.4 with dummy variables for the year of and two years following the law change. The more general dynamic structure actually strengthens the long-run effect of unilateral, although the estimate of $0.536(0.065)$ is not statistically different from the estimate in regression 3.4. The lag dummies have negative coefficients, revealing that the long-run effect was attained gradually. In the year of the law change, the impact was to raise the divorce rate by 0.419 [0.536-0.117], and in the following year by 0.446 [0.5360.090]. The results demonstrate another reason why the estimate of unilateral's impact was attenuated using Peters' and Allen's data - it was a cross-section in the late 1970s, during the transition from mutual to unilateral divorce in many states.

Another issue involves the appropriate length of the panel. A long panel is useful, in principle, for capturing the background changes in divorce patterns over time. However, if the linear, or even quadratic, state trends are misspecified, then a longer panel could lead to a worse instead of better fit. If, further, the changing state divorce propensities are correlated with the adoption of unilateral divorce, then the longer is the panel and the worse the fit of the state trends, the more biased might become the estimate of unilateral. Most states switched to 
unilateral divorce in the 1970 s, so the question that arises is whether the extra observations in the 1980s add useful information to the specification or worsen the estimate of unilateral.

To see whether the extra years of data alter the estimates, regression 5.5 in Table 5 cuts off the sample at 1979 - still encompassing more than nine-tenths of the law changes. The estimate of unilateral's impact in regression 5.5 is only slightly different, at $0.438(0.055)$ compared to $0.447(0.050)$ in regression 3.4. The standard error is higher as well, not surprisingly. Adding one year at a time to the sample period from 1980 on induces relatively small, though not trivial, changes in the coefficient estimates, which range from 0.421 to 0.485. A partial explanation for this pattern arises from the evidence just noted of a gradual response of divorce rates in the remaining states switching to unilateral divorce. Adding years of data also improves the F-statistic testing the joint significance of the state trends. Therefore, the estimates do not indicate that the extra years of data, in which few states actually adopted unilateral divorce, distort the estimate of unilateral, but instead that they help in identifying the underlying trends in state divorce propensities. ${ }^{19}$

\section{Additional Features of the Estimation}

The estimated coefficients on the fixed effects and trends are of interest in themselves because they generate most of the explanatory power in the regressions. The coefficients on the year effects, which control for unobserved factors that affect divorce nationally, are significant and quite large, although adding state trends in regressions 3.4 and 3.5 reduces their magnitude a little and raises their standard errors. The pattern of the year effects mirrors the divorce trends in Figure 1, with the coefficients growing bigger through the 1970s, peaking around 1980 , and then stabilizing. Thus, whatever were the factors common across the nation that affected divorce - more liberal attitudes towards divorce, for example - they increasingly raised divorce rates until 1980, after which their influence steadied.

\footnotetext{
19 Since the estimates do not provide any conclusive evidence about when to cut off the panel, I chose to use data up to the latest year available.
} 
The coefficients on the state effects and trends from regression 3.4, shown in Table 6, tell us about geographical patterns in divorce propensities. Large negative intercepts are prevalent in the Northeastern and North Central states, so the propensity of their residents to divorce was the lowest at the beginning of the sample. But while starting low, the propensity to divorce rose somewhat in parts of the region, indicated by the positive coefficients on the slopes. Residents of Southern states generally began with a moderate propensity to divorce that rose over the period, indicated by intercept coefficients close to zero and positive slope coefficients. Residents of Western states started with the greatest propensity to divorce, which moderated in some states. ${ }^{20}$

Lastly, given the wide variation in divorce trends across states, a final check of whether unilateral is capturing other effects involves adding other state-level covariates to the regression. They might affect divorce but might not be captured fully by the state fixed effects and trends. Additional variables corresponding to Peters' covariates - education, race, urbanization, income, employment - were extracted for women from the March Current Population Survey (CPS) and aggregated by state each year using the CPS weights. Including the extra variables in the regression leaves the coefficient on unilateral virtually unchanged. ${ }^{21}$ This confirms that the state fixed effects and trends are capturing the important influences on divorce.

20 The intercept and slope coefficients on Nevada are noticeably large because Nevada is a divorce haven, with very short residency requirements. This would bias upward the coefficient on unilateral if a couple that would have divorced in Nevada now divorces at home - a story corroborated by Nevada's large negative slope coefficient. However, the very high divorce rate in Nevada is misleading because Nevada has an extremely small resident population. Divorces in Nevada have ranged between nine and fifteen thousand since the late 1960s, while nationwide divorces hit one million in 1975 and kept rising. The percentage of nationwide divorces obtained in Nevada, while closer to $2 \%$ in the 1960 s, has been in the neighborhood of $1 \%$ since then. Those magnitudes will not have much of an impact in estimating the coefficient on unilateral with weighted least squares.

21 The coefficient on unilateral changes at most at the fourth decimal place. None of the state-level variables are significant at the $90 \%$ confidence level. The joint $\mathrm{F}$-statistics on the state fixed effects and trends decline slightly but remain significant at better than $99.9 \%$. Before 1978 , not all states are identified separately in the CPS, reducing the sample size by 274 . 


\section{CONCLUSION}

Using panel data sheds new light on the impact of the no-fault revolution on divorce rates. It shows that the way one controls for geographical heterogeneity affects the estimation considerably, as Peters and Allen already demonstrated. But further, it shows that controlling flexibly for unobserved attributes of state populations that are correlated with both divorce behavior and the divorce law is crucial. This is made possible by using longitudinal divorce data. I assembled a panel of state level divorce rates, which measures virtually every divorce in the U.S. over the entire duration of the law changes. The estimation reveals a strong influence of unilateral divorce: divorce rates would have been about $6 \%$ lower if states had not adopted unilateral divorce, accounting for $17 \%$ of the overall increase between 1968 and 1988. The current move to tightening divorce requirements can therefore be expected to lower the number of divorces. However, the estimates also demonstrate that other factors in addition to unilateral and no-fault divorce had a great deal to do with the increase in divorces in the U.S. 


\section{REFERENCES}

Allen, Douglas, W. "Marriage and Divorce: Comment." American Economic Review, June 1992, 82, 679-85.

Becker, Gary S. A Treatise on the Family, Cambridge: Harvard University Press, 1981.

Brinig, Margaret F., and F.H. Buckley. "No-Fault Laws and At-Fault People." International Review of Law and Economics.

Cherlin, Andrew J. Marriage, Divorce, Remarriage, Cambridge: Harvard University Press, 1992.

Freed, Doris Jonas, and Henry H. Foster, Jr. "Divorce in the Fifty States: An Outline." Family Law Quarterly, Fall 1977, 11, 297-313.

Freed, Doris Jonas, and Henry H. Foster, Jr. "Divorce in the Fifty States: An Overview as of 1978." Family Law Quarterly, Spring 1979, 13, 105-28.

Freed, Doris Jonas, and Henry H. Foster, Jr. "Divorce in the Fifty States: An Overview." Family Law Quarterly, Winter 1981, 14, 229-47.

Freed, Doris Jonas, and Walker, Timothy R. "Family Law in the Fifty States: An Overview." Family Law Quarterly, Winter 1990, 23, 495-608.

Gruber, Jonathan, and Maria Hanratty. "The Labor Market Effects of Introducing National Health Insurance: Evidence from Canada." Journal of Business and Economic Statistics, April 1995, 13, 163-73.

Jacobson, Louis S., Robert J. LaLonde and Daniel G. Sullivan. "Earnings Losses of Displaced Workers." American Economic Review, September 1993, 83, 685-709.

Leland, John. “Tightening the Knot.” Newsweek, February 19, 1996, 127, 72-3.

Peters, H. Elizabeth. "Marriage and Divorce: Informational Constraints and Private Contracting." American Economic Review, June 1986, 76, 437-54.

Peters, H. Elizabeth. "Marriage and Divorce: Reply." American Economic Review, June $1992,82,686-93$. 
Sepler, Harvey J. "Measuring the Effects of No-Fault Divorce Laws Across Fifty States: Quantifying a Zeitgeist." Family Law Quarterly, Spring 1981, 15, 65-102.

Vital Statistics of the United States. 1960-1988.

\section{APPENDIX}

Dummy variables were created to account for the following irregularities in the data on divorce rates:

$\begin{array}{lll}\text { State } & \text { Time Period } & \text { Reason } \\ \text { Kentucky } & 1978-1984 & \text { incomplete } \\ \text { Mississippi } & 1979,1984-1985 & \text { incomplete } \\ \text { Arkansas } & 1973-1974,1980,1982-1985 & \text { incomplete } \\ \text { New Mexico } & 1968-1973,1981-1982,1986-1987 & \text { incomplete } \\ \text { New Mexico } & 1981-1982,1984-1985 & \text { divorce petitions filed } \\ \text { California } & 1984-1986 & \text { include legal separations } \\ \text { Ohio } & 1981-1985 & \text { incomplete } \\ \text { Indiana } & 1968-1969,1974,1977-1986 & \text { include divorce petitions } \\ \text { Indiana } & 1970-1977 & \text { incomplete } \\ \text { Oklahoma } & 1970-1974 & \text { include divorce petitions } \\ \text { Arizona } & 1968-1972 & \text { include divorce petitions } \\ \text { Michigan } & 1988 & \text { incomplete } \\ \text { District of Columbia } & 1987-1988 & \text { valid divorce certificates } \\ \text { Mississippi } & 1988 & \text { incomplete } \\ \text { New Mexico } & 1988 & \text { incomplete } \\ \text { California } & 1988 & \text { incomplete }\end{array}$

Louisiana had incomplete data for the entire series, which is accounted for in the estimation by the Louisiana state effect. The regression results are quite similar when these observations are omitted. 
TABLE 1: Divorce Laws, by States

(1)

(2)

(3)

(4)

Unilateral Unilateral divorce, including Unilateral divorce,

State separation requirements no-fault settlement only Since

Alabama

Alaska

Arizona

Arkansas

divorce

$\sqrt{ }$
$\sqrt{ }$
$\sqrt{ }$

no

no, separation req but separ-

ation must be mutually agreed

California

Colorado

Connnecticut

Delaware

Dist Columbia

Florida

Georgia

Hawaii

Idaho

Illinois

Indiana

Iowa

Kansas

Kentucky

Louisiana

Maine

Maryland

Massachusetts

$\sqrt{ }$

$\sqrt{ }$

no, fault settlement 1971

\begin{tabular}{l|l}
$\sqrt{ }$ & $\checkmark$
\end{tabular}

a

$\sqrt{ }$
$\sqrt{ }$

pre 1968

\begin{tabular}{|c|c|c|c|c|}
\hline Massachusetts & $\sqrt{ }$ & $\sqrt{ }$ & no, fault settlement & 1975 \\
\hline Michigan & $\sqrt{ }$ & $\sqrt{ }$ & no, fault settlement & 1972 \\
\hline Minnesota & $\sqrt{ }$ & $\sqrt{ }$ & $\sqrt{ }$ & 1974 \\
\hline Mississippi & no & no & no & - \\
\hline Missouri & no & $\sqrt{ }, 2$ year separation required & $\sqrt{ }$ & 1973 \\
\hline
\end{tabular}




\begin{tabular}{|c|c|c|c|c|}
\hline State & $\begin{array}{c}(1) \\
\text { Unilateral } \\
\text { divorce } \\
\end{array}$ & $\begin{array}{c}(2) \\
\text { Unilateral divorce, including } \\
\text { separation requirements }\end{array}$ & $\begin{array}{c}\text { (3) } \\
\text { Unilateral divorce, } \\
\text { no-fault settlement only } \\
\end{array}$ & $\begin{array}{r}(4) \\
\text { Since } \\
\end{array}$ \\
\hline Montana & $\sqrt{ }$ & $\sqrt{ }$ & $\sqrt{ }$ & 1975 \\
\hline Nebraska & $\sqrt{ }$ & $\sqrt{ }$ & $\sqrt{ }$ & 1972 \\
\hline Nevada & $\sqrt{ }$ & $\sqrt{ }$ & $\sqrt{ }$ & 1973 \\
\hline New Hampshire & $\sqrt{ }$ & $\sqrt{ }$ & no, fault settlement & 1971 \\
\hline New Jersey & no & $\checkmark, 18 \mathrm{mth}$ separation required & no, fault settlement & 1971 \\
\hline New Mexico & $\sqrt{ }$ & $\sqrt{ }$ & $\sqrt{ }$ & 1973 \\
\hline New York & no & no & no & - \\
\hline North Carolina & no & $\begin{array}{l}\sqrt{ }, 1 \text { year separation required, } \\
\text { need agreement on alimony }\end{array}$ & no, fault settlement & $\begin{array}{c}\text { pre } \\
1968^{*}\end{array}$ \\
\hline North Dakota & $\sqrt{ }$ & $\sqrt{ }$ & no, fault settlement & 1971 \\
\hline Ohio & no & $\checkmark, 1$ year separation required & no, fault settlement & 1974 \\
\hline Oklahoma & $\sqrt{ }$ & $\sqrt{ }$ & $\sqrt{ }, 1975$ & pre 1968 \\
\hline Oregon & $\sqrt{ }$ & $\sqrt{ }$ & $\sqrt{ }$ & 1973 \\
\hline Pennsylvania & no & $\begin{array}{l}\sqrt{ }, 3 \text { year separation req, and } \\
\text { court says marriage broken }\end{array}$ & no, fault settlement & $1980^{*}$ \\
\hline Rhode Island & $\sqrt{ }$ & $\sqrt{ }$ & no, fault settlement & 1976 \\
\hline South Carolina & no & $\sqrt{ }, 3$ yr separation req; then 1 & no, fault settlement & 1969 \\
\hline South Dakota & $\sqrt{ }$ & $\sqrt{ }$ & no, fault settlement & 1985 \\
\hline Tennessee & no & no, 2 yr separation if no kids & no & - \\
\hline Texas & $\sqrt{ }$ & $\sqrt{ }$ & no, fault settlement & 1974 \\
\hline Utah & no & $\sqrt{ }, 3$ year separation required & no, fault settlement & pre 1968 \\
\hline Vermont & no & $\sqrt{ }, 6$ mth separation required & no, fault settlement & pre 1968 \\
\hline Virginia & no & $\sqrt{ }, 2$ year separation required & no, fault settlement & pre 1968 \\
\hline Washington & $\sqrt{ }$ & $\sqrt{ }$ & $\sqrt{ }$ & 1973 \\
\hline West Virginia & no & $\sqrt{ }, 2$ yr separation req; then 1 & no, fault settlement & pre 1968 \\
\hline Wisconsin & no & $\begin{array}{l}\sqrt{ }, 1 \text { year voluntary separa- } \\
\text { tion; if one disputes, court } \\
\text { decides if irreconcilable diffs }\end{array}$ & $\sqrt{ }$ & $1977^{*}$ \\
\hline Wyoming & $\sqrt{ }$ & $\sqrt{ }$ & no, fault settlement & 1977 \\
\hline
\end{tabular}


(1) $\sqrt{ }$, state has unilateral divorce. Unilateral divorce is defined as requiring the consent of only one spouse and granted on no-fault grounds. No-fault grounds include irretrievable breakdown, irreconcilable differences, and/or incompatibility.

(2) $\sqrt{ }$, state has unilateral divorce, with the no-fault grounds now including separation for a required length of time.

(3) $\checkmark$, state has unilateral divorce, and also does not allow fault grounds to be considered for property settlement and alimony.

(4) Year when unilateral divorce instituted. If the law change occurred in the second half of the year, then it is attributed to the following year. * Definition of unilateral divorce is disputable. The estimation results were not found to be sensitive to the classification of these states.

Source: State annotated legal codes, Sepler (1981), Peters (1986), Freed and Walker (1990), Brinig and Buckley (1996). 


\begin{tabular}{|c|c|c|c|c|}
\hline \multicolumn{5}{|c|}{ TABLE 2: Divorce Rates, by States } \\
\hline \multirow[b]{2}{*}{ State } & \multicolumn{4}{|c|}{ Average Divorce Rate: Divorces per 1000 people } \\
\hline & $1968-72$ & $1973-77$ & 1978-82 & $1983-88$ \\
\hline Alabama & 4.4 & 6.1 & 6.7 & 6.2 \\
\hline Alaska & 5.6 & 7.6 & 8.5 & 7.2 \\
\hline Arizona & 7.0 & 7.4 & 7.3 & 6.8 \\
\hline Arkansas & 5.5 & 6.9 & 6.9 & 6.8 \\
\hline California & 4.9 & 5.9 & 5.6 & 5.1 \\
\hline Colorado & 4.7 & 6.4 & 6.3 & 5.8 \\
\hline Connecticut & 2.1 & 3.6 & 4.3 & 3.7 \\
\hline Delaware & 2.9 & 4.6 & 5.0 & 4.8 \\
\hline District of Columbia & 3.3 & 4.6 & 6.2 & 4.2 \\
\hline Florida & 5.8 & 7.2 & 7.2 & 6.7 \\
\hline Georgia & 4.0 & 5.7 & 6.2 & 5.5 \\
\hline Hawaii & 3.6 & 4.9 & 4.7 & 4.5 \\
\hline Idaho & 4.9 & 6.2 & 6.8 & 6.1 \\
\hline Illinois & 3.4 & 4.3 & 4.5 & 4.2 \\
\hline Indiana $^{1}$ & 4.6 & 6.1 & 7.0 & 6.3 \\
\hline Iowa & 2.6 & 3.5 & 3.9 & 3.7 \\
\hline Kansas & 3.8 & 5.2 & 5.5 & 5.1 \\
\hline Kentucky & 3.3 & 4.2 & 4.3 & 5.0 \\
\hline Louisiana $^{2}$ & 2.7 & 3.2 & 3.8 & 3.6 \\
\hline Maine & 3.7 & 4.9 & 5.5 & 5.0 \\
\hline Maryland & 2.4 & 3.7 & 4.0 & 3.6 \\
\hline Massachusetts & 2.1 & 2.8 & 3.1 & 3.2 \\
\hline Michigan & 3.4 & 4.6 & 4.7 & 4.3 \\
\hline Minnesota & 2.2 & 3.3 & 3.8 & 3.5 \\
\hline Mississippi & 3.6 & 5.0 & 5.4 & 4.9 \\
\hline Missouri & 3.9 & 5.0 & 5.5 & 5.0 \\
\hline Montana & 4.4 & 5.7 & 6.2 & 5.3 \\
\hline
\end{tabular}




\begin{tabular}{||l||c|c|c|c||}
\hline State & $1968-72$ & $1973-77$ & $1978-82$ & $1983-88$ \\
\hline Nebraska & 2.5 & 3.6 & 4.1 & 3.9 \\
\hline Nevada & 20.9 & 17.2 & 16.2 & 14.2 \\
\hline New Hampshire & 3.5 & 5.0 & 5.5 & 4.8 \\
\hline New Jersey & 1.7 & 2.8 & 3.6 & 3.6 \\
\hline New Mexico & 4.3 & 7.3 & 7.8 & 7.8 \\
\hline New York & 1.5 & 3.0 & 3.5 & 3.7 \\
\hline North Carolina & 2.8 & 4.0 & 4.8 & 4.9 \\
\hline North Dakota & 1.7 & 2.7 & 3.3 & 3.4 \\
\hline Ohio & 3.6 & 4.9 & 5.3 & 4.8 \\
\hline Oklahoma & 6.3 & 7.6 & 7.8 & 7.4 \\
\hline Oregon & 4.7 & 6.3 & 6.7 & 5.8 \\
\hline Pennsylvania & 2.0 & 2.9 & 3.3 & 3.3 \\
\hline Rhode Island & 1.6 & 3.0 & 3.7 & 3.8 \\
\hline South Carolina & 2.3 & 3.3 & 4.3 & 4.1 \\
\hline South Dakota & 2.1 & 3.2 & 3.9 & 3.7 \\
\hline Tennessee & 4.2 & 6.1 & 6.5 & 6.3 \\
\hline Texas & 4.7 & 5.9 & 6.6 & 5.9 \\
\hline Utah & 3.8 & 4.9 & 5.3 & 5.1 \\
\hline Vermont & 2.2 & 3.8 & 4.6 & 4.5 \\
\hline Virginia & 2.6 & 3.8 & 4.5 & 4.3 \\
\hline Washington & 5.3 & 6.9 & 6.8 & 6.0 \\
\hline West Virginia & 3.0 & 4.5 & 5.3 & 5.0 \\
\hline Wisconsin & 2.0 & 2.9 & 3.7 & 3.5 \\
\hline Wyoming & 5.6 & 7.1 & 8.0 & 7.2 \\
\hline \hline $\begin{array}{l}1 \\
\text { Data are for 1968-69, 1974, } \\
\text { for 1970, 1974-80, 1983-85. }\end{array}$ \\
Averages across years computed using annual state population for weights. & & \\
\hline & & & & \\
\hline
\end{tabular}




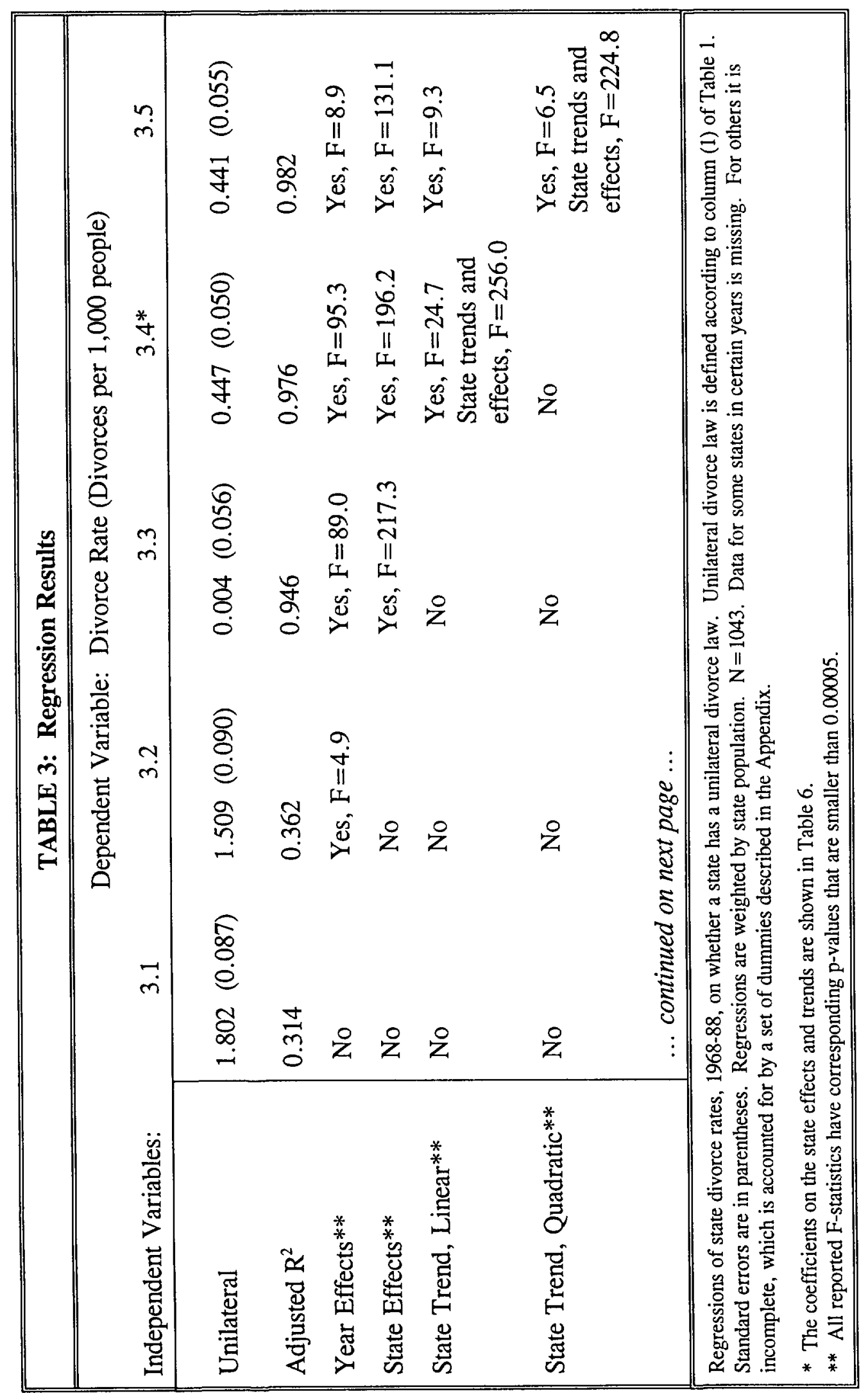




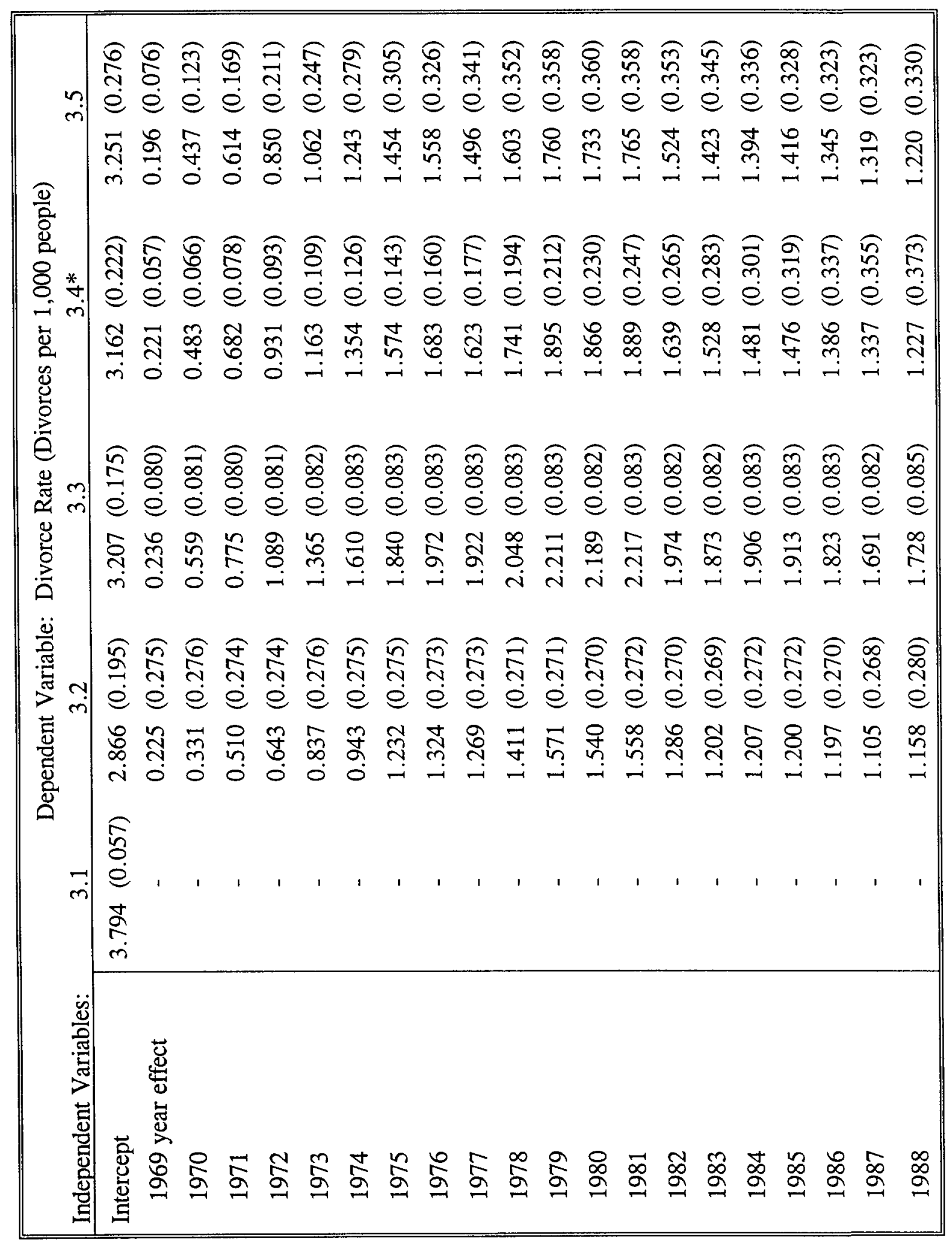


TABLE 4: Alternative Classifications of Divorce Laws

\begin{tabular}{|c|c|c|c|c|c|c|}
\hline \multicolumn{7}{|c|}{ Dependent Variable: Divorce Rate (Divorces per 1,000 people) } \\
\hline & & 3.4 & 4.1 & 4.2 & 4.3 & 4.4 \\
\hline \multicolumn{2}{|l|}{$\begin{array}{l}\text { Unilateral } \\
\text { Defined as: }\end{array}$} & $\begin{array}{c}0.447 \\
(0.050)\end{array}$ & $\begin{array}{c}0.450 \\
(0.050)\end{array}$ & $\begin{array}{c}0.454 \\
(0.050)\end{array}$ & $\begin{array}{c}0.545 \\
(0.068)\end{array}$ & $\begin{array}{c}0.549 \\
(0.067)\end{array}$ \\
\hline \multirow{2}{*}{$\begin{array}{l}\text { Grounds for } \\
\text { divorce }\end{array}$} & Other no-fault & $\sqrt{ }$ & $\sqrt{ }$ & $\sqrt{ }$ & $\sqrt{ }$ & $\sqrt{ }$ \\
\hline & Separation & & & & \multirow{3}{*}{$\sqrt{ }$} & \multirow{3}{*}{$\sqrt{ }$} \\
\hline \multirow{2}{*}{$\begin{array}{l}\text { Grounds for } \\
\text { property }\end{array}$} & No-fault & $\sqrt{ }$ & $\sqrt{ }$ & $\sqrt{ }$ & & \\
\hline & Fault & $\sqrt{ }$ & $\sqrt{ }$ & $\sqrt{ }$ & & \\
\hline \multicolumn{2}{|c|}{ Grounds for divorce: Separation } & - & $\begin{array}{c}0.167 \\
(0.059) \\
{[0.0002]}\end{array}$ & - & - & - \\
\hline \multicolumn{2}{|c|}{ Separation for 6 months } & - & - & $\begin{array}{c}0.145 \\
(0.616)\end{array}$ & - & - \\
\hline \multicolumn{2}{|l|}{12 months } & - & - & $\begin{array}{c}0.511 \\
(0.100)\end{array}$ & - & - \\
\hline \multicolumn{2}{|l|}{18 months } & - & - & $\begin{array}{c}-0.111 \\
(0.156)\end{array}$ & - & - \\
\hline \multicolumn{2}{|l|}{24 months } & - & - & $\begin{array}{c}0.085 \\
(0.097)\end{array}$ & - & - \\
\hline \multicolumn{2}{|l|}{36 months } & - & - & $\begin{array}{c}0.055 \\
(0.111)\end{array}$ & - & - \\
\hline \multicolumn{2}{|l|}{60 months } & - & - & $\begin{array}{c}0.191 \\
(0.216) \\
\end{array}$ & - & - \\
\hline \multicolumn{2}{|c|}{ Grounds for property: Fault } & - & - & - & $\begin{array}{c}0.392 \\
(0.056) \\
{[0.033]}\end{array}$ & - \\
\hline \multirow{3}{*}{\multicolumn{2}{|c|}{$\begin{array}{l}\text { Grounds for divorce: Other no-fault } \\
\text { Grounds for property: Fault } \\
\text { Grounds for divorce: Separation } \\
\text { Grounds for property: No-fault } \\
\text { Grounds for divorce: Separation } \\
\text { Grounds for property: Fault }\end{array}$}} & - & - & - & - & $\begin{array}{c}0.396 \\
(0.056)\end{array}$ \\
\hline & & - & - & - & - & $\begin{array}{c}0.133 \\
(0.091)\end{array}$ \\
\hline & & - & - & - & - & $\begin{array}{c}0.192 \\
(0.078) \\
\end{array}$ \\
\hline \multicolumn{2}{|l|}{ Adjusted $\mathrm{R}^{2}$} & 0.976 & 0.976 & 0.976 & 0.976 & 0.976 \\
\hline
\end{tabular}




\begin{tabular}{|c|c|c|c|c|c|c|c|}
\hline & \multicolumn{7}{|c|}{ Dependent Variable: Divorce Rate (Divorces per 1,000 people) } \\
\hline & 3.4 & 5.1 & 5.2 & 5.3 & 5.4 & & 5.5 \\
\hline Unilateral & $\begin{array}{c}0.447 \\
(0.050)\end{array}$ & $\begin{array}{c}0.449 \\
(0.057)\end{array}$ & $\begin{array}{c}0.468 \\
(0.054)\end{array}$ & $\begin{array}{c}0.489 \\
(0.060)\end{array}$ & $\begin{array}{c}0.536 \\
(0.065)\end{array}$ & \multirow{7}{*}{$\begin{array}{l}\text { Sample } \\
\text { restricted } \\
\text { to: }\end{array}$} & $\begin{array}{c}0.438 \\
(0.055)\end{array}$ \\
\hline $\begin{array}{l}\text { Dummy for } \\
\text { law change } \\
\text { occurring: }\end{array}$ & & & & & & & $\begin{array}{l}1968- \\
1979\end{array}$ \\
\hline $\begin{array}{l}1 \text { period } \\
\text { later }\end{array}$ & - & $\begin{array}{c}0.004 \\
(0.067)\end{array}$ & - & - & - & & - \\
\hline $\begin{array}{l}\text { In this } \\
\text { period }\end{array}$ & - & - & $\begin{array}{l}-0.060 \\
(0.062)\end{array}$ & $\begin{array}{l}-0.076 \\
(0.065)\end{array}$ & $\begin{array}{l}-0.117 \\
(0.069)\end{array}$ & & - \\
\hline 1 period ago & - & - & - & $\begin{array}{c}-0.055 \\
(0.063)\end{array}$ & $\begin{array}{l}-0.090 \\
(0.066)\end{array}$ & & - \\
\hline $\begin{array}{l}2 \text { periods } \\
\text { ago }\end{array}$ & - & - & - & - & $\begin{array}{l}-0.108 \\
(0.062)\end{array}$ & & - \\
\hline Adjusted $\mathrm{R}^{2}$ & 0.976 & 0.976 & 0.976 & 0.976 & 0.976 & & 0.983 \\
\hline $\begin{array}{l}\text { See the notes to } \\
\text { effects, state ef } \\
\text { Table } 1 \text {. }\end{array}$ & $\begin{array}{l}\text { ble } 3 \text { for } \\
\text { s, and li }\end{array}$ & ore detail. & $\begin{array}{l}\text { tandard er } \\
\text {. Unilater }\end{array}$ & $\begin{array}{l}s \text { are in } p \\
\text { livorce is }\end{array}$ & $\begin{array}{l}\text { entheses. } \\
\text { fined her }\end{array}$ & $\begin{array}{l}\text { egressions } i \\
\text { ccording to }\end{array}$ & $\begin{array}{l}\text { ude year } \\
\text { lumn (1) of }\end{array}$ \\
\hline
\end{tabular}




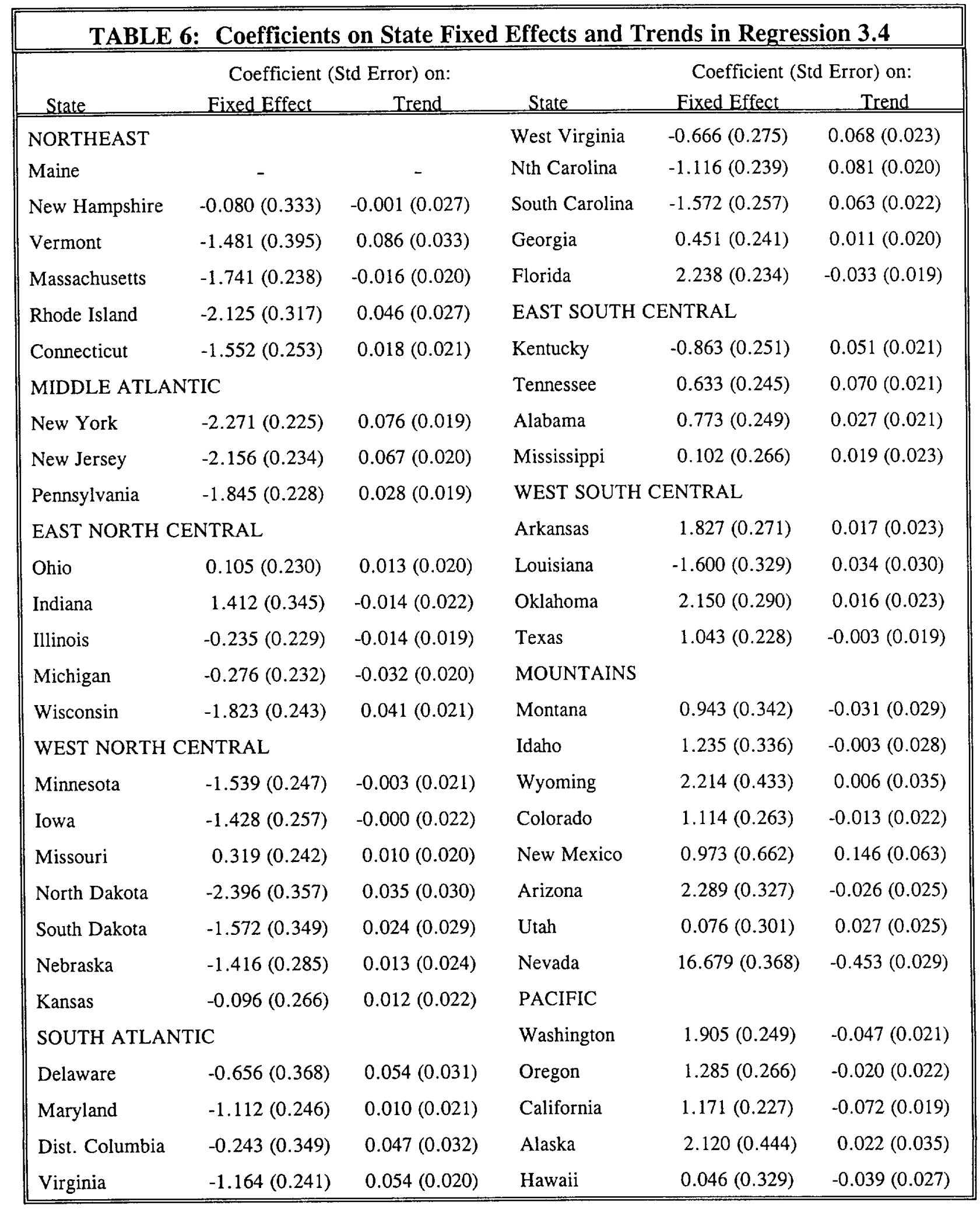


Figure 1

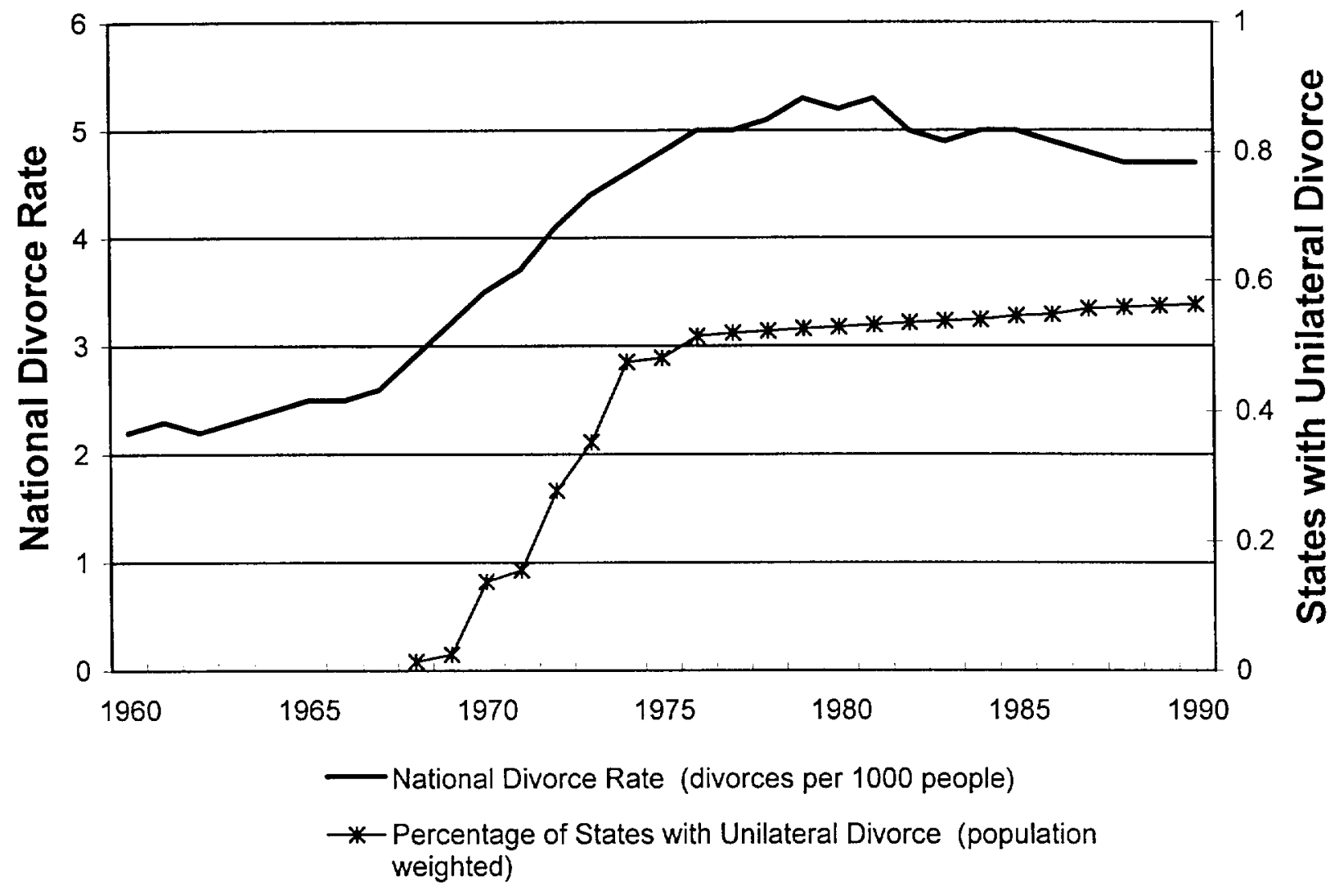


Figure 2-A

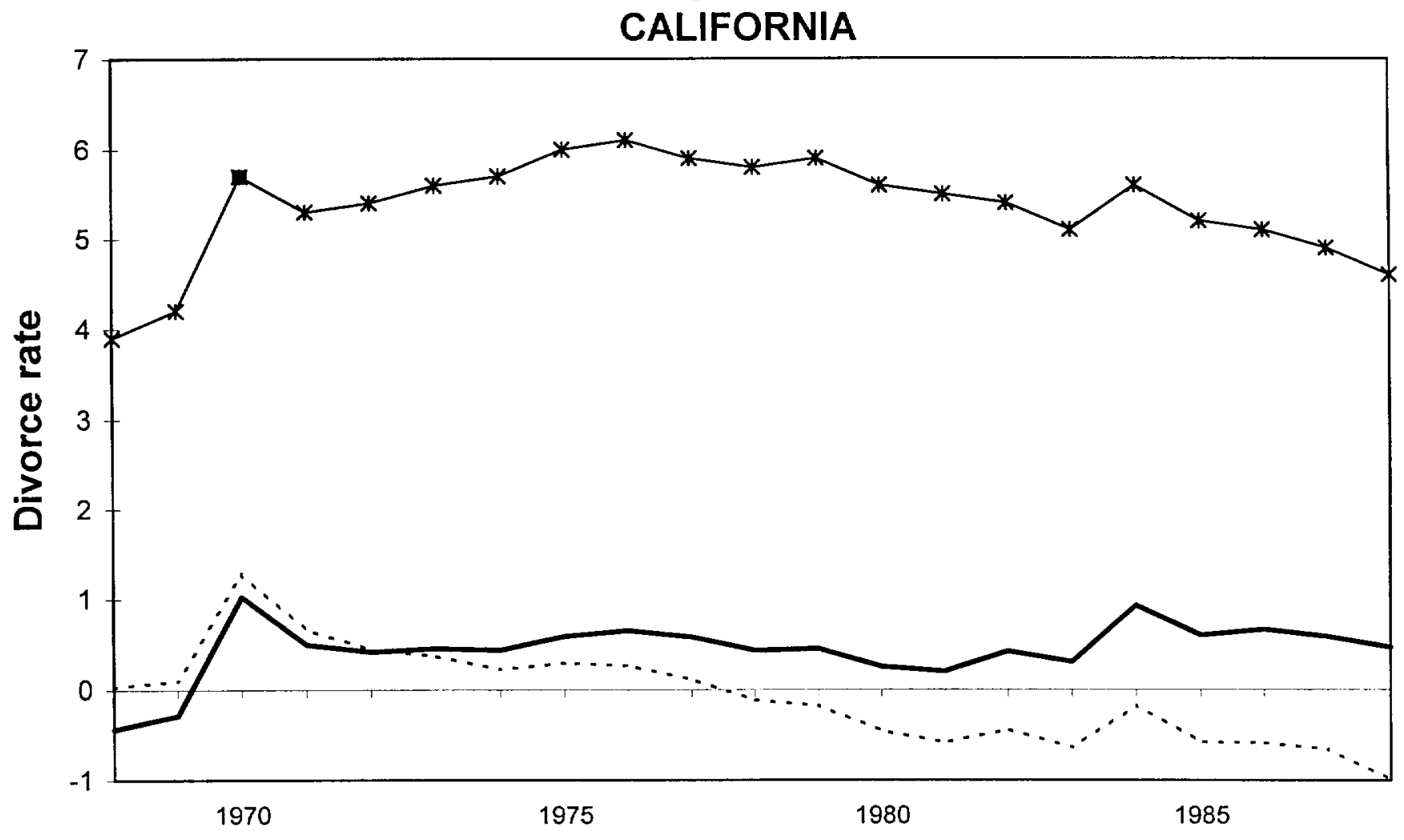

- Law change Regression residuals, $\cdots \cdots$ no state trends *-Divorce rate to be explained by law: with state trends 
Figure 2-B

MICHIGAN

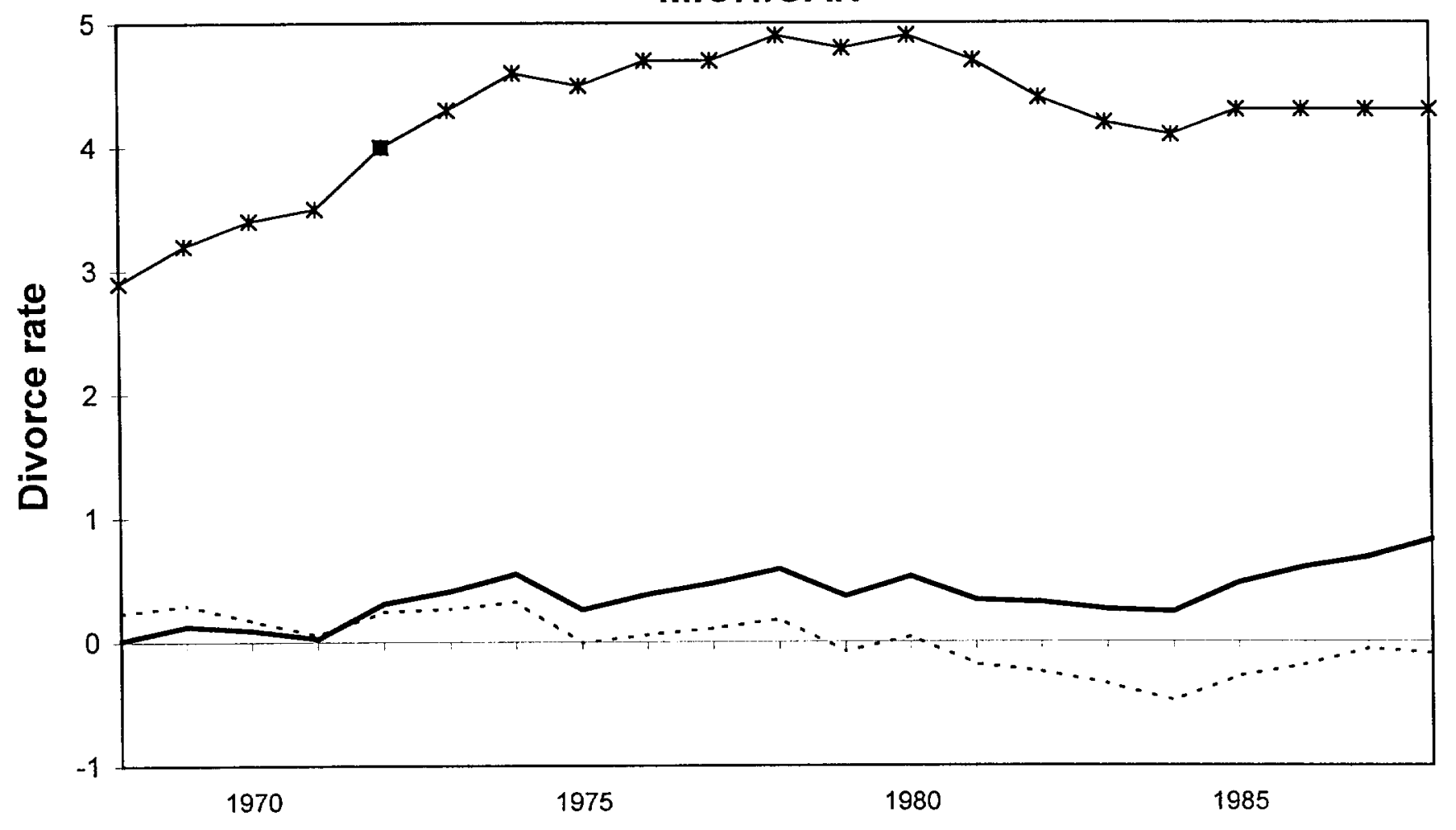

- Law Change

Regression residuals,... no state trends

*-Divorce rate

to be explained by law: — with state trends 